\title{
ASSESSMENT OF IMPACT OF CAPITAL ACQUISITIONS ON THE ECONOMIC SITUATION OF CONSOLIDATED ENTITIES IN THE CZECH REPUBLIC
}

\author{
Jaroslava Rajchlová로 Anna Fedorová2, Kristína Somerlíková1, Libor Grega ${ }^{1}$ \\ ${ }^{1}$ Department of Regional and Business Economics, Faculty of Regional Development and International Studies, \\ Mendel University in Brno, Zemědělská 1, 61300 Brno, Czech Republic \\ ${ }^{2}$ Department of Finance, Faculty of Business and Management, University of Technology, Antonínská 1, \\ 60190 Brno, Czech Republic
}

To link to this article: https://doi.org/10.11118/actaun201967051335

Received: 13. 8. 2018, Accepted: 27. 8. 2019

To cite this article: RAJCHLOVÁ JAROSLAVA, FEDOROVÁ ANNA, SOMERLÍKOVÁ KRISTÍNA, GREGA LIBOR. 2019. Assessment of Impact of Capital Acquisitions on the Economic Situation of Consolidated Entities in the Czech Republic. Acta Universitatis Agriculturae et Silviculturae Mendelianae Brunensis, 67(5): 1335-1345.

\begin{abstract}
Business acquisition constitutes a fundamental aspect of business environment formation. Our research has focused on assessment of impact of capital acquisition on the economic condition of the company. Therefore, the second research level has been initiated, focusing on the individual assessment of the single companies to identify allocation of synergy between consolidated units and parent companies in the Czech Republic. For our research, taking into consideration availability of data and subsequent explanatory value of the results, we will consider synergistic effect as presented in the Ansoff's concept. Consolidated financial statements of totally 719 groups of accounting entities - business concerns in the Czech Republic has been studied in the research. A composite indicator, as the modern tool for comparison and evaluation of development of entities, has been selected to compare individual economic indicators of parent companies and group of their companies. We believe that developed arguments allow us to formulate conclusion that capital acquisitions, resulting in the years 2008-2013 in the obligation to compile consolidated financial statement, have brought positive financial synergistic effects in majority of cases, and we can rank them among successful business activities.
\end{abstract}

Keywords: acquisition, consolidated reporting entities, synergistic effect, composite indicator, economic indicators

\section{INTRODUCTION}

Economic transformation of the Czech Republic has not been completed yet, though passing through its final stage. Therefore, fusions and mergers are still a highly topical issue. This opinion is underpinned by conclusions reached by the consulting services company "Ernst Young", periodically publishing information dealing with this issue, e.g., the M\&A Barometr H1 2017 Czech Republic. As indicated in the report, in the long run the Czech Republic ranks among countries with the greatest number of mergers and acquisitions in the Central and Southeastern Europe. The greatest boom was experienced in 2016 with the highest number of acquisitions (totally 288). In 2017, the Czech Republic ranked second with 246 acquisitions. Nevertheless, acquisition and merger market itself increased by $16 \%$ as to the volume of transactions. Compared with last year, the market rose to USD 11.5 billion, representing the second largest market 
in the reporting countries. The trend towards increase in foreign investments, activated by Czech investors, has been noticed recently.

Our research project focuses on the assessment of impact of capital acquisitions on the economic situation of the company. Assessment of impacts of mergers (as the method to connect companies) has been excluded as this method would not provide better insight into the possible change in the economic development of the company after its integration.

Business acquisition constitutes a fundamental aspect of business environment formation. Justification for acquisitions is predominantly based on the promise of wealth accumulated from various resources, from synergistic effects of differentiation up to the change in the company management. Irrespective of the reasons, the major argument put forward by the managers is that takeover/ acquisition makes the business more efficient and, finally, increases yields of shareholders both in the target and acquiring company. Thus, improvement in the overall effectiveness, which would not be possible before merger and acquisition with companies operating in the market individually, is a significant contribution of the acquisition (Ray, 2010). Gugler et al. (2003) sets out main methods of performance improvement in the target companies: economies of scale, improved capacity utilization, lower transaction costs compared to the market relations or, for instance, acquisition and transfer of new resources and abilities. Besides, stronger market power of the company adds an extra value.

These effects are called "synergistic effects of acquisition". The synergistic effect is usually the driving force behind acquisition. The question can be phrased, i.e., how to understand and interpret synergistic effects. Two different approaches to synergies can be adopted.

First basic approach: the concept of synergy by Ansoff. The Ansoff (1965) concept is based on the understanding that exploitation of common resources (resources together) is greater than individually; in other words, synergy is an effect which might generate greater combined profitability of the company resources rather than pure sum of their individual parts. Synergy achievement is the only one decision criterion, applied by Ansoff. Ansoff distinguishes four possible synergistic effects through their impacts: turnover increase, cost reduction, liability reduction, and management synergies. His concept of synergy indicates that synergies must always be positive. Ansoff rather believed the contrary; nevertheless, he did not follow negative synergies, their causes and reasons. Thus, Ansoff's model does not reliably identify change in the value of the company through net synergy.

The second approach: the concept of synergy by Porter. Porter (1987) seeks to reach positive synergy through value chain and interaction between the individual forces: manufacturing, markets, procurement, technology, and infrastructure. Porter recognizes synergistic effect as the change in the value of the company as a whole, through changes in revenues and, at the same time, costs or through pure cost reduction, demonstrated by higher value of the new company in contrast to the sum of values of the individual companies. Acquisition process is successful only if the created value exceeds costs generated by the acquisition itself. However, synergistic effect is accomplished only if and when the value and performance of two companies combined are greater than the simple sum of the separate individual acquiring and target companies. Generally, synergy comes in from better utilization of resources, economies of scale, stronger market power as a result of smaller business competition, effective work of new management or higher debt capacity, and lower costs of debt.

For our research, taking into consideration availability of data and subsequent explanatory value of the results, we will consider synergistic effect as presented in the Ansoff's concept. Assuming the existence of both positive and negative synergistic effect, we will hereinafter use the term "positive synergistic effect". The positive synergistic effect expects cost savings, revenue increase, improved production capacity utilization, market share increase, exploitation of skills and experience, more effective innovation process etc.

The positive synergy may also be understood as the change in the individual sub-indicators if focusing on financial indicators, it would be a positive synergy in the finances, i.e., so-called financial synergy in harmony with the concept of synergy by Ansoff.

Identification of financial synergy is deemed to be more provable as compared to other synergies, in particular by consolidation of the individual financial statements; results of investigations into other synergies are more debatable considering internal company problems and differing cultures (McGee et al., 2014).

Numerous pieces of research, dating from the 1960s to now, have shown a broad spectrum of results of impacts of acquisitions on the economic situation of the company. Either market data or accounting values of target companies are monitored. Both company valuation methods have certain limits. For instance, market value of shares reflects expectations, atmosphere in the society, political situation, economic cycle stages, industry at a specific time. Accounting values follow systematized accounting data; however, certain accounting principles may optimize them. From our perspective, explanatory value of accounting data is higher just because of soundness of outputs and availability of relevant values. Therefore, our research will be based on the accounting data and will identify financial synergies as an outcome of acquisition in the conditions of the Czech Republic. 
Contribution of financial synergy to the company resides in higher cashflow and reduced total costs of capital. The following segments can fall within the category of financial synergies (according to Darmodoran, 2005):

- higher profitability, most frequently by connection between large company, with surplus cash, and small company with less cash. However, the small company has projects in which the large company can invest its surplus cash. In addition, higher profitability is achieved by shared supplementary services, access to larger distribution network, more efficient marketing. In addition, increased sales are generated by better innovations of the product, introduced by merger of companies;

- interest tax shield. Stabilization of cashflow and yields of joint companies allow companies to borrow more funds than each company individually. Tax advantage is based on lower costs of capital;

- tax advantage gained by reduced tax base of the parent company on the basis of loss suffered by the subsidiary company;

- synergies from diversification are also frequent acquisition objectives. Not only focuses the company on a single product/service, but also makes an effort to diversify its risk, when one market might be jeopardized by the economic environment.

Diverse empirical studies have surveyed performance of target companies; increase in revenues for shareholders after the acquisition has never been confirmed (e.g., Gregory, 1996; Kennedy and Limmack, 1996; Sudarsanam, 2003). Aiming at results of studies, examining accounting data of target companies, we should mention the study of Meeks (1977), who analyzed performance of 233 British organizations (acquiring companies) between 1964 and 1972. Outcomes indicated that profitability of companies increased in the year of acquisition; however, subsequently declined over the next five years. The study, carried-out by Ravenscroft and Scherer (1987), concluded (surveying totally 471 companies from 1950 until 1976) that companies reported decrease in profitability after completed acquisition. Healy et al. (1992) found that acquisition improved productivity of assets, contributed to higher operating cash flow and company performance compared to the control group, not acquired. I.e., Healy arrived at the conclusion that acquisitions mitigated negative impacts on companies. Identically to Andrade et al. (2001), who looked at 2,000 acquisitions completed in the USA between 1973 and 1998, and assumed that return on sales (ROS) of target companies improved when compared to the national economy. Authors concluded that operating performance of acquiring and target companies was better in contrast to the performance of the control group. Various approaches are favored to evaluate financial synergies, very often financial ratios. For instance, these ratios were applied in the research carried out from 1979 to 1984, evaluating 50 largest acquisitions until then. Acquisitions were evaluated by indicators of total assets turnover ratio, return on sales and changes in number of employees compared with the previous year, with the clear result of positive financial synergy (Damodaran, 2005).

Another survey by Huyghebaert \& Luypaert (2010) studied acquisitions, applying (for operating synergies) the indicator measuring intangible assets minus goodwill to the total assets. For financial synergies, Huyghebaert \& Luypaert used the ratio of bank credits to total assets, again with the positive effect.

In 2009, the author Svobodová from the Vysoká škola ekonomická (the University of Economics) completed her survey carried-out in the Czech Republic; her research compared success of mergers and acquisitions in the context of comparison with the industrial Czech averages; reached conclusions confirmed higher values of the absolute indicators in case of merged and target companies compared to the mentioned averages. Nonetheless, conclusions of Svobodová (2009) did not make it absolutely clear as whether expected synergistic effect of acquisitions occurred.

\section{Objectives of Solution}

We have assessed impacts of capital acquisitions on the consolidated entities running in three levels. The first level, i.e., the first objective, conducted in 2016, has been to identify positive synergistic effects between the consolidated entity and the parent company (if any) as to the financial synergy in the conditions of the Czech Republic. The first research objective has proved positive financial synergy of the consolidated units in the Czech Republic measured between 2008-2013.

Subsequently, the second research level has been initiated (in 2017), focusing on the individual assessment of single parent companies and consolidated units to identify allocation of financial synergy just between consolidated units and parent companies in the Czech Republic. The subjectmatter of this outcome is presentation of the second research level, i.e., an individual assessment of the single consolidated units and parent companies. To accomplish this objective, we have defined a unique model of evaluation of economic health of consolidated units and parent companies. The model is based on the composite indicator principle. In addition, detection of resistance of consolidated units to economic fluctuations is another subobjective.

The following research questions may be formulated: What is the economic health of consolidated units compared to parent companies? What is the economic stability of consolidated units in the period of economic fluctuations? 
The third objective is to find out whether some industry differences (if any) can be identified as regards the financial positive synergy in the Czech Republic. We assume to investigate into the third research level in the near future.

Submitted research is quite unique from the point of examination of accomplishment of the financial positive synergistic effect of acquisitions in the Czech Republic.

\section{MATERIALS AND METHODS}

Consolidated financial statements of totally 719 groups of accounting entities - business concerns in the Czech Republic has been studied in the research. I.e., the statistical population consist of 719 consolidated units, which can be considered as the total population of all published consolidated financial statements ${ }^{1}$. This statement is supported by the fact that Obchodní rejstřík (Trade Register) has provided us with data upon the prior consent of the Ministry of Justice. We have narrowed the group of target companies to the consolidated subjects based on the complex economic view on the group, offering the processing of accounting data by the consolidated financial statement. The essence of consolidated accounting financial statement consists of the consolidation, if the full method of consolidation is applied, of all accounting data for the consolidated unit and, at the same time, elimination of internal financial processes; a cleared view on the group of companies is presented. Therefore, we consider consolidated financial statement as document providing the highest possible level of accounting information about the group.

Procedures of consolidated financial statement compilation are defined in the act on accounting, Act No. 563/1991 Coll. According to the Czech legislation, full method of consolidation is applied, used for companies with decisive influence, i.e., 40\% and higher share in the voting rights in the company. Full method of consolidation means summarization of all accounting items, elimination of internal operations and so-called minority shares in the company assets. Another consolidation method is the equivalency method, employed in the exercise of the substantial influence, i.e., 20\%-39\% share in the voting rights in the company. Equivalency method determines share in the economic results depending on the share in the equity capital, identified as the share in the economic results in equivalency. The last consolidation method is a proportional method, applied in case of two equal shares in the voting rights of the company where both shares are decisive.
Compilation rules, applied to the consolidated financial statement, are strictly set forth by the act on accounting. Consequently, consolidated financial statement may be regarded as the relevant source of information about economic situation of the business group.

In the first stage of research, a methodology for determination of positive synergistic effect of the business concerns must be framed. Given the fact that views on the positive synergistic effect are consistent, we will operate with measurable phenomena meeting the financial synergistic effect.

To determine these economic indicators, we have built on the conclusions from analyses of the scientific literature dealing with the financial management of business concerns; Perridon et al. (2009), Rudolph (1998), Reisch (1998) and others consent to the need to provide:

- cash position ratio as the basic concept in the business,

- return on equity as the unique indicator of venture capital assessment,

- cost management, which we can see in determination of the return on sales as the indicator of the total cost ratio of the company, economies of scale or, possibly, as the cost reduction.

Scientific literature describes synergistic effect as the financial savings - we talk about financial stability; liabilities can be drawn in a cheaper manner and in higher volumes. Monitoring of indebtedness level might be recommended. The research (Dluhošová et al., 2013) reveals that decreasing cash position ratio is accompanied with rising indebtedness. To accept this point of view, positive-satisfactory values of the cash position indicator can be considered as a satisfactory indebtedness. In contrast, low cash position ratio would mean high indebtedness.

The following path for the cash position ratio calculation has been used:

short-term financial assets/current liabilities;

Return on equity (ROE) calculation:

net income/shareholder's equity;

Return on sales (ROS):

net income before interest and tax /total sales.

In the second stage of the research, underlying documents from the Trade Register have been surveyed to calculate, process and analyze characteristics of all 719 company groups (from 2008 until 2013).

A composite indicator - as the modern tool for comparison and evaluation of development of entities - has been selected to compare individual economic indicators of parent companies and group of their companies. The composite indicator

1 According to the Act on Business Corporations, Act No. 90/2012 Coll., a consolidated unit means a business grouping consisting of controlling and controlled entities and/or units under significant influence. 
creates a presumption for compilation of thresholds necessary for existence of the model of evaluation of economic health of consolidated units and parent companies. In spite of the fact that from a purely mathematic point of view the indicator is a trivial construction, its purpose is to aggregate results of more sub-indicators into the single composite indicator. Thus, the composite indicator stands for a certain synthesis of information, provided by selected sub-indicators, presenting a partial view on the certain aspect of the monitored subject.

From objectively logical aspect, indicators should be distinguished as whether achievement of the highest level (indicators "max") is desirable, indicators where - on the contrary - the lowest level is desirable (indicators "min”) and last but not least also indicators "opt”, where achievement of certain "optimum" value is desirable. In our case, indicators "max" have been used for all selected variables.

Sub-indicators are usually incomparable; therefore, they are normalized. As to the identical units of measure of the monitored sub-indicators, standardization of mentioned values has not been necessary. Another step is determination of weight of sub-variables, unless we consider them as equally important. With regards to the monitored economic quantities, all three monitored sub-indicators have been assigned with equal weights. This decision has been supported by already existing model of the "index of total performance of the company (ICV)”, created by researches from the Vysoká škola ekonomická (the University of Economics) in 2000, where equal weights are used for groups of data of the indicators of ROE, ROS, and cash position ratio.

The composite indicator, as the tool of the model of evaluation of economic health of consolidated units and parent companies created by us, has been formed as a weighted sum of the mentioned three indicators (weight equals to one). Based on the calculated composite indicator, monitored subjects have been ordered from the highest to the lowest values for each reference year; furthermore, required comparisons have been made subsequently. To determine composite indicator, both consolidated unit and the individual accounting entity must have at their disposal all data necessary to calculate all monitored financial indicators in all monitored years.

Our research, as to its structure, has not been conducted in the Czech Republic yet; thus, we consider our survey as unique. The investigation offers a perspective and answer to the question how financial positive synergies are allocated in the consolidated units in the Czech Republic, both as to the valuation and impact of acquisitions on the economic situation of the consolidated units.

\section{Findings of the Research}

Tab. I clearly sets out values of the composite indicator of the organizations - consolidated units - and parent companies - individual accounting entities for the reported period, i.e., from 2008 until 2013. For the entire period, we can notice a large excess of higher values reached for the consolidated units compared to the parent companies. The comparison relies on established values of the composite indicator of the individual consolidation unit and its parent company. Difference in the number of companies shown in the line called "totally" reflects collection of all monitored values of both subjects. Quantities of consolidated units have varied over the years.

In Tab. I, we may see a constant characteristic situation where ca. $60 \%$ of the consolidated units show better values of the monitored economic indicators, transformed into the value of the composite indicator, compared to their parent companies. Taking into account the logic of financial synergy, as explained above, we can talk about its accomplishment.

Tab. I. is not indicative of the general economic climate of the monitored entities. To complete this analysis, a model evaluating economic situation of both consolidated units and individual accounting entities - parent companies has been drafted. Socalled recommended values for the individual economic indicators have been applied: return on equity (ROE) seems problematic for values below

I: Comparison of the composite indicator values of parent companies and consolidated units

\begin{tabular}{|c|c|c|c|c|c|c|}
\hline Year & 2013 & 2012 & 2011 & 2010 & 2009 & 2008 \\
\hline $\begin{array}{l}\text { Number of concerns with higher value of the indicator than the Parent } \\
\text { company - A }\end{array}$ & 81 & 122 & 143 & 144 & 147 & 139 \\
\hline $\begin{array}{l}\text { Number of concerns with lower value of the indicator than the parent } \\
\text { company }-\mathrm{N}\end{array}$ & 49 & 82 & 93 & 97 & 100 & 74 \\
\hline Total & 130 & 204 & 236 & 241 & 247 & 213 \\
\hline$\% \mathrm{~A}$ & $62 \%$ & $60 \%$ & $61 \%$ & $60 \%$ & $60 \%$ & $65 \%$ \\
\hline$\% \mathrm{~N}$ & $38 \%$ & $40 \%$ & $39 \%$ & $40 \%$ & $40 \%$ & $35 \%$ \\
\hline
\end{tabular}

Source: authors' elaboration

Notes to the Tab. I:

A - the concern has higher value of the indicator than the company

$\mathrm{N}$ - the concern has lower value of the indicator than the company 
5\%; satisfactory rate oscillates around 9\%; return on sales (ROS) seems problematic for values below $3 \%$. Average value lies within the range 3\%-5\%.

Cash position ratio indicator involves risk for values below 0.2. Recommended range varies from 0.2 to 0.5 .

For all monitored indicators, we build on the generally accepted conclusions - the higher their value, the better condition of the monitored entity. Therefore, these indicators could be used to construct the composite indicator.

Some experts believe that high level of cash position ratio is undesirable, but only because of unexploited excess financial resources. However, this fact does not pose a threat to the company such as, on the contrary, too low value of the indicator. Low value of the indicator may result in insolvency, inability of fulfill financial obligations, and bankruptcy.

Tab. II shows intervals of values defining the level of economic situation of the individual as well as consolidated subject. The model of evaluation of economic health of the entities takes into account the sum of relative expression of values of indicators of rentability and cash position ratio for the individual scales of evaluation. All three indicators are mutually complementary. ROS also means the total cost ratio. If the total cost ratio, TCR, is high, i.e., ROS percentage low, then it is probable that both cash position ratio and ROE will be lower. However, contrary statement may not be expected, i.e., if the cash position ratio is satisfactory then also satisfactory values of returns are detected.

Evaluation in the category "poor" assumes that all values of composite indicators below 0.28 suggest poor economic situation of the entity. The category "satisfactory" means the interval of composite indicator from 0.29 to 0.64. As anomalies have occurred, the authors are aware of the fact that the company with zero returnability may be filed in this category (where VH is negative; therefore, ROE values must equal to zero) and, at the same time, the company with the cash position ratio over 0.29; nevertheless, only a couple of entities has been affected. In general terms, if zero returnability is identified, the cash position ratio is very low and the subject has been integrated into the previous category. The category "good" includes subjects with the composite indicator over 0.65 .

Tab. II shows percentage distribution of the composite indicator values for the consolidated units. The table summarizes that $24 \%-31 \%$ of the consolidated units (2008-2013) fall into the category "poor", i.e., ca. 70-76\% belong to the category "satisfactory" and "good". The highest percentage of companies, i.e., between $35 \%-44 \%$, is included in the category "good". It is interesting to note that in 2008-2010, i.e., in the years of severe economic crisis, consolidated units reported better values of the composite indicator than in years 2012-2013, when the economic growth was reported.

To establish nature of the financial synergy, i.e., positive or negative, a model for the individual accounting units - parent company (Tab. III) has been developed. Findings are as follows:

- 31\%-43\% of the companies belong to the category "poor" in all years under consideration;

- i.e., 57\%-69\% of the companies are included in the category "satisfactory" and "good";

- percentage of entities falling into the category "good" ranges from 33\% to 41\%.

Findings published in Tab. I, i.e., that in ca. $60 \%$ of cases the consolidated units are in better economic situation than the parent companies, are completed and extended by the data contained in Tab. II and Tab. III.

ROE and cash position ratio values, published in the Financial Analyses of the Ministry of Industry and Trade (see Tab. IV), have been found to assess situation of the consolidated units in the conditions of the national economy of the Czech Republic as a whole during the reference period. Cash position ratio, calculated by the Ministry of Industry

II: Percentage distribution of the composite indicator values for the consolidated units

\begin{tabular}{lccc}
\hline & Poor & Satisfactory & Good \\
\hline ROE & $0-0.05$ & $0.051-0.089$ & $0.09-$ over \\
ROS & $0-0.03$ & $0.031-0.05$ & 0.051 -over \\
Cash position ratio & $0-0.2$ & $0.21-0.5$ & $0.51-$ over \\
Range of values of the composite indicator & $0-0.28$ & $0.29-0.64$ & $0.65-$ over \\
\hline 2013 & $31 \%$ & $34 \%$ & $35 \%$ \\
2012 & $27 \%$ & $34 \%$ & $39 \%$ \\
2011 & $24 \%$ & $31,8 \%$ & 44,1 \\
2010 & $29 \%$ & $28 \%$ & $42 \%$ \\
2009 & $28 \%$ & $29 \%$ & $44 \%$ \\
2008 & $24 \%$ & $32 \%$ & $43 \%$ \\
\hline
\end{tabular}

Source: authors' elaboration 
III: Percentage distribution of the composite indicator values for the individual accounting entities

\begin{tabular}{llcl}
\hline & Poor & Satisfactory & Good \\
\hline ROE & $0-0.05$ & $0.051-0.089$ & $0.09-0 v e r$ \\
ROS & $0-0.03$ & $0.031-0.05$ & $0.051-0 v e r$ \\
Cash position ratio & $0-0.2$ & $0.21-0.5$ & $0.51-$ over \\
Range of values of the composite indicator & $0-0.28$ & $0.29-0.64$ & $0.65-0 v e r$ \\
\hline 2013 & $43 \%$ & $22 \%$ & $34 \%$ \\
2012 & $34 \%$ & $29 \%$ & $37 \%$ \\
2011 & $31 \%$ & $30 \%$ & $39 \%$ \\
2010 & $36 \%$ & $23 \%$ & $41 \%$ \\
2009 & $38 \%$ & $25 \%$ & $37 \%$ \\
\hline S & $39 \%$ & $28 \%$ & $33 \%$ \\
\hline
\end{tabular}

Source: authors' elaboratio

IV: Average values of ROE and cash position ratio for the national economy

\begin{tabular}{lcccccc}
\hline \multicolumn{1}{c}{ Indicator/year } & 2013 & 2012 & 2011 & 2010 & 2009 & 2008 \\
\hline Average value of ROE for the national economy & $5.33 \%$ & $6.88 \%$ & $7.33 \%$ & $8.71 \%$ & $8.59 \%$ & $11.71 \%$ \\
Average value of cash position ratio for the national economy & 0.56 & 0.55 & 0.5 & 0.43 & 0.41 & 0.3 \\
\hline
\end{tabular}

Source: authors' elaboration

and Trade, is identical to the cash position ratio calculation as made in our research.

Breakdown of companies by industrial sectors is essential to paint a comprehensive picture of the issue of capital acquisitions in the Czech Republic. As definition of the field of business of the consolidated unit is impossible because of industrially differentiated companies forming the unit, we have rated economic subjects by the activity pursued by the parent company. The analysis refers to the year 2014. In view of the massive differentiation between results of the individual industries, any year-on-year changes can not be expected, resulting in differences in the years when the main survey has been conducted to identify financial synergies. Most frequently, in $32 \%$, capital acquisition of parent companies has been reported in the processing industry, the second position (around 20\% from the total number of parent companies) has been occupied by parent companies involved in the trade, repairs of motor vehicles and products for personal consumption and third, with $14 \%$, in the real estate and lease, followed by (10\%) from the total amount by companies involved in the construction engineering. Other areas are either negligible by reason of their extent or no acquisitions have been completed in the particular industry. More detailed description of results for the individual industries will be studied in-depth within our next research plan, which we label as the third level of the research plan of the assessment of impact of the capital acquisitions on the economic situation of the consolidated units in the Czech Republic.

Fig. 1 depicts development of average ROE of the consolidated units and average ROE value in the national economy. In all years, consolidated units report higher values of ROE indicator. Values vary between ca. 10\% in the year 2013 and ca. 16\% in the year 2010 (and 2012) in the reporting period.

The fact that values of economic indicators for the companies, which we have monitored, have not been separated, do not prevent us to express a qualified opinion. Should averages of values for the national economy be calculated for the companies without consolidated units, ROE values would certainly be lower. The highest approximation was reported in 2008; the national economy showed average ROE value $12 \%$ and the consolidated units $14 \%$. These two values differed mostly in the year 2012 , i.e., already in the period of economic growth.

In the same way as the average of ROE indicator, the cash position ratio of the consolidated units is higher compared to the average cash position ratio of the companies in the national economy in the reporting period. Rather lower average indebtedness of the consolidation units may be identified on the basis of average values of the cash position ratio. In total, values for the consolidation units can be considered as so-called "satisfactory", identically to the values reported for the national economy. 


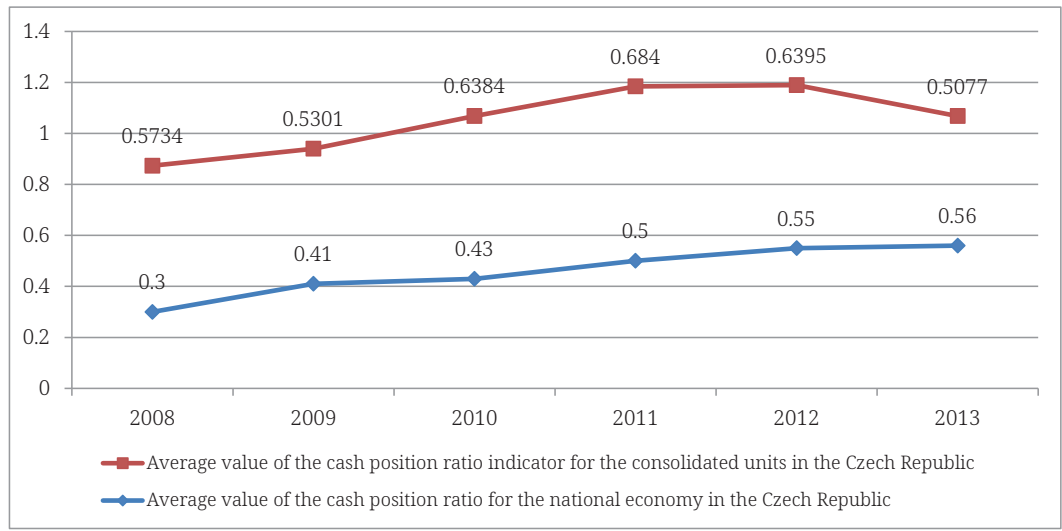

1: Graph of comparison of the average values of ROE of the consolidated units and companies of the national economy

Source: authors' elaboration

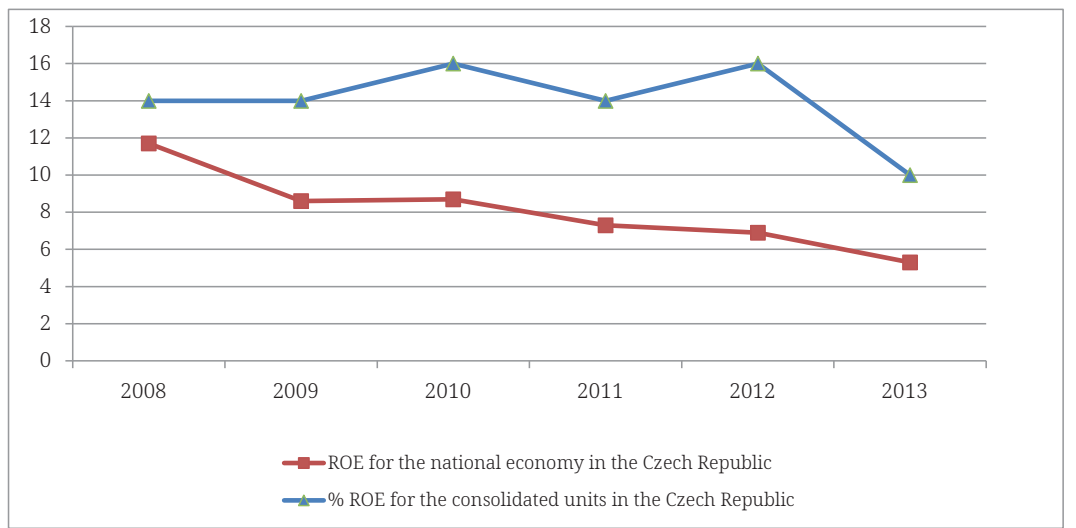

2: Graph of comparison of values of cash position ratio of the consolidated units and companies in the national economy

Source: authors' elaboration

\section{DISCUSSION}

Percentage distribution of the economic health of the consolidated units and parent companies, shown in Tab. II and Tab. III, proves that economic subjects with the capital acquisition, are - as a whole - more successful than their parent companies. In aggregate, these units are highly above average of monitored values reported by the national economy. Therefore, we can talk about accomplishment of positive financial synergistic effects in the conditions of the national economy.

Nevertheless, this statement does not mean that the Czech capital acquisitions are unconditionally successful. Success rate of acquisitions is often evaluated on the basis of expectations of investors, which we do not know.

However, from the company-economic point of view, achieved parameters demonstrated by the consolidated units can be regarded as good economic results and the indisputable economic health of the significant part (ca. annually $40 \%$ in average) of the consolidated units in the Czech Republic can be recognized for the given period. It is evident that good principles of financial management are applied in the companies, generating savings and economies of scale. We can support this statement by comparison of values between the parent company and the consolidated unit. We highlight importance of the financial management of the entire group, not only the individual companies. If mentioned principles are not applied within the group, such values of the economic indicators and positive financial synergistic effects would not be achieved.

Reports of the Český statistický úrad (2015) (the Czech Statistical Office) conclude that the Czech economy (in the period from 2008 until 2013) was influenced by the imported crisis, triggered by a collapse in demand. The Czech economy was not hit by the global crisis, but the world-wide economic crisis. The year 2009 is considered as the critical year for the Czech Republic, years 20082010 as the critical period. The most catastrophic impact was on the employment - year-on-year decrease in the employment rate started from the first quarter of 2009; however, year-on-year declines were reported for most of 2008 - besides continuous decline in the primary production - also 
in the construction engineering, trade, and public administration. Throughout 2009, the number of employees fell steadily in all sectors except for construction engineering, food and drink services and accommodation, also in the industry of real estate and services for companies. The greatest employment losses in 2009 were announced in the processing industry, with year-on-year decrease by $8.8 \%$ in the fourth quarter. Consolidated units dominated these sectors. As can be read in Fig. 1, average ROE value for the year 2009 was 14\%, in the year 2010 amounted to 16\%. Identically, percentage of companies in the area (according to Tab. II) "good" is high, more than $40 \%$ of all consolidated units are in the good economic condition. It is evident that groups of companies are more resistant to economic fluctuations than the individual accounting units (Tab. III). Diversification effect may play an important role as the characteristic feature of acquisition is diversification of business risk by broad portfolio of services or products.

Management of groups responded to worsening economic conditions by cost reduction; indisputable financial background of the groups enabled to stand declining demand. A conservative strategic management of companies as applied by managers could play a certain role, demonstrated by high cash position ratio (see Fig. 2). It is rather clear that consolidated units actively apply so-called "cashpooling", the effect of which is better utilization of internal financial funds of the consolidated unit, minimized cost of capital and reduced transaction costs.

Research conclusions justify us to identify ourselves with the outcomes of Healy et al. (1992), confirming effects of acquisitions manifested by the improved performance of the company with the conclusion that acquisitions helps to mitigate negative impacts on companies, or conclusions of Andrade et al. (2001), affirming that performance of companies after the acquisition is better than performance of companies included in the so-called control group.

As stated in the introduction, contrasting conclusions on the impact of acquisitions on the economic situation of companies have been expressed. In the context of conclusions contrary to each other, research questions have been framed: What is the economic health of consolidated units compared to parent companies? What is the economic stability of consolidated units in the period of economic fluctuations?

In the conditions of the Czech Republic, the research revealed that economic situation of the consolidated units, on which we have focused on as they could provide us with the comprehensive accounting data for the group, show positive financial synergistic effects.

Introduced model of the economic health of the consolidated units can be used as a tool for comparison of studied consolidated units with companies all around the Czech Republic.

Developed arguments allow us to formulate conclusion that capital acquisitions, resulting in the years 2008-2013 in the obligation to compile consolidated financial statement, have brought positive financial synergistic effects in majority of cases, and we can rank them among successful business activities. Identically, we consider risk diversification of consolidated units as the base for their resistance to economic fluctuations.

\section{CONCLUSION}

Business acquisition constitutes a fundamental aspect of business environment formation. Justification for acquisitions is predominantly based on the promise of wealth accumulated from various resources, from synergistic effects of differentiation up to the change in management. Our research has focused on assessment of impact of capital acquisition on the economic condition of the company. Therefore, the second research level has been initiated, focusing on the individual assessment of the single companies to identify allocation of synergy between consolidated units and parent companies in the Czech Republic.

Assessment of impacts of mergers (as the method to connect companies) has been excluded as this method would not provide better insight into the possible change in the economic development of the company after its integration.

For our research, taking into consideration availability of data and subsequent explanatory value of the results, we will consider synergistic effect as presented in the Ansoff's concept. Assuming the existence of both positive and negative synergistic effect, we will hereinafter use the term "positive synergistic effect". The positive synergy may also be understood as the change in the individual subindicators - if focusing on financial indicators, it would be a positive synergy in the finances.

Consolidated financial statements of totally 719 groups of accounting entities - business concerns in the Czech Republic has been studied in the research. We have narrowed the group of target companies to the consolidated subjects based on the complex economic view on the group, offering the processing of accounting data by the consolidated financial statement. Given the fact that views on the positive synergistic effect are consistent, we will operate with measurable phenomena meeting the financial synergistic effect: cash position ratio, return on equity, and return on sales. 
A composite indicator, as the modern tool for comparison and evaluation of development of entities, has been selected to compare individual economic indicators of parent companies and group of their companies. The composite indicator has been formed as a weighted sum of the mentioned three indicators (weight equals to one). Based on the calculated composite indicator, monitored subjects have been ordered from the highest to the lowest values for each reference year; furthermore, required comparisons have been made subsequently. To determine composite indicator, both consolidated unit and the individual accounting entity must have at their disposal all data necessary to calculate all monitored financial indicators in all monitored years.

For the entire period, i.e., the years 2008-2013, we can notice a large excess of higher values reached for the consolidated units compared to the parent companies. Ca. 60\% of the consolidated units show better values of the monitored economic indicators, transformed into the value of the composite indicator, compared to their parent companies. Taking into account the logic of financial synergy, as explained above, we can talk about its accomplishment.

To complete this analysis, a model evaluating economic situation of both consolidated units and individual accounting entities - parent companies has been drafted. On the grounds of results achieved by the application of the model of evaluation of the economic situation it was found that ca. $70 \%-75 \%$ of the consolidated units belong to the category "satisfactory" and "good". As to the parent companies, ca. 57\%-69\% are in the category "satisfactory" and "good". Comparing ROE and cash position ratio indicators for the national economy, it has been noted that values of the consolidated units are always higher. Therefore, we can talk about accomplishment of the positive financial synergistic effects in the conditions of the national economy. Nevertheless, this statement does not mean that the Czech capital acquisitions are unconditionally successful. Success rate of acquisitions is often evaluated on the basis of expectations of investors, which we do not know. However, from the company-economic point of view, achieved parameters demonstrated by the consolidated units can be regarded as good economic results and the indisputable economic health of the significant part (ca. annually 40\%in average) of the consolidated units in the Czech Republic can be recognized for the given period. It is evident that good principles of financial management are applied in the companies, generating savings and economies of scale. We can support this statement by comparison of values between the parent company and the consolidated unit. On the basis of assessment of the economic condition of the consolidated units and national economy in the context of the economic crisis it has been established that groups of companies are more resistant to economic fluctuations than the individual accounting units. Management of groups responded to worsening economic conditions by cost reduction; indisputable financial background of the groups enabled to stand declining demand. A conservative strategic management of companies as applied by managers could play a certain role, demonstrated by high cash position ratio and/or cash pooling application. We believe that developed arguments allow us to formulate conclusion that capital acquisitions, resulting in the years 2008-2013 in the obligation to compile consolidated financial statement, have brought positive financial synergistic effects in majority of cases, and we can rank them among successful business activities.

\section{Acknowledgements}

This paper was prepared in the framework of the project IGA of Mendel University in Brno entitled "The importance of strategy and strategic management of small and medium-sized enterprises primarily focused on e-commerce” with the registration number FRRMS - IGA - 2018/003.

\section{REFERENCES}

ANDRADE, G., MiTCHELL, M. L. and STAFFORD, E. 2001. New Evidence and Perspectives on Mergers. Journal of Economic Perspectives, 15(2): 103-120.

ANSOFF, H. I. 1965. Corporate Strategy: An Analytic Approach to Business Policy for Growth and Expansion. New York: McGraw-Hill.

DAMODARAN, A. 2005. The Value of Synergy. Stern School of Business. Available at: http://people.stern. nyu.edu/adamodar/pdfiles/papers/synergy.pdf [Accessed: 2018, December 15].

DLUHOŠOVÁ, D. 2008. Financial management and business decision-making: analysis, investment, valuation, risk, flexibility [in Czech: Finanční řizení a rozhodování podniku: analýza, investování, oceňování, riziko, flexibilita]. Praha: Ekopress.

ERNST AND YUNG. 2017. The M\&A Barometr H1 2017 Czech Republic. Available: http://www.ey.com/ Publication/vwLUAssets/EY_MA_Barometr_H1_2017_2/\$FILE/MA_Barometer_CR_H1_17.pdf [Accessed: 2018, December 15]. 
GREGORY, A. 1997. An examination of the long run performance of UK acquiring firms. Journal of Business Finance and Accounting, 24(7-8): 971-1002.

GUGLER, K., MUELLER, D. C., YURTOGLU, B. B. and ZULEHNER, C. 2003. The effects of mergers: an international comparison. International Journal of Industrial Organisation, 21(1): 625-653.

HEALY, P. M., PALEPU, K. G. and RUBACK, R. 1996. Does corporate performance improve after mergers? Journal of Financial Economics, 31(3): 135-175.

HUYGHEBAERT, N. and LUYPAERT, M. 2010. Antecedents of growth through mergers and acquisitions: Empirical results from Belgium. Journal of Business Research, 63(4): 392-403.

KENNEDY, V. A. and LIMMACK, R. J. 1996. Takeover activity, CEO turnover and the market for corporate control. Journal of Business Finance and Accounting, 23(2): 267-285.

MEEKS, G. 1977. Disappointing Marriage: A Study of the Gains from Merger. New York: Cambridge University Press.

MCGEE, J. and CHAMMON, D. F. 2014. Synergy. In: COOPER, C. L. et al. (Eds.). Wiley Encyclopedia of Management: Strategic Management. Vol. 12. John Wiley \& Sons.

PORTER, M. E. 1987. Diversification - Groups without concept [in German: Diversifikation - Konzerne ohne Konzept]. Harvard Business Manager, 9(4): 30-49.

PERRIDON, L., STEINER, M. and RATHGEBER, A. W. 2009. Financial management of the underlay [in German: Finanzwirtschaft der Unterlegung]. 13 ${ }^{\text {th }}$ Edition. Munchen: Verlag Franz Vahlen.

RAVENSCROFT, D. and SCHERER, F. M. 1987. Life after takeovers. Journal of Industrial Economics, 36(4): 147-156.

RAY, K. G. 2010. Mergers and Acquisitions: Strategy, Valuation and Integration. New Delhi: PHI Learning Private Limited.

REISCH, R. 1998. The corporate finance policy [in German: Die Konzern-Finanzpolitik]. In: LUTTER, M., SCHEFFLER, E. and SCHNEIDER, U. H. (Eds.). Handbuch der Konzernfinanzierung. Köln, pp. 137152.

RUDOLPH, B. 1998. The Group-wide financing rules and capital structure [in German: Die konzerweiteten Finanzierungsregeln und Kapitalstruktur] In: LUTTER, M., SCHEFFLER, E. and SCHNEIDER, U. H. (Eds.). Handbuch der Konzernfinanzierung. Köln, pp. 153-170.

SUDARSANAM, S. and MAHATE, A. A. 2003. Glamour acquirers, method of payment and postacquisition performance: the UK evidence. Journal of Business Finance and Accounting, 30(1-2): 299-341.

SVOBODOVÁ, I. 2009. Success of mergers and acquisitions in the Czech Republic [in Czech: Hodnoceni úspěšnosti fúzí a akvizicí v České republice]. Dissertation Thesis. Praha: VšE.

Contact information

Jaroslava Rajchlová: rajchlov@mendelu.cz

Anna Fedorová: fedorova@fbm.vutbr.cz

Kristína Somerlíková: somerlik@mendelu.cz

Libor Grega: grega@mendelu.cz 